CLINICAL STUDY

\title{
The pubertal transition in 179 healthy Danish children: associations between pubarche, adrenarche, gonadarche, and body composition
}

\author{
Annette Mouritsen ${ }^{1}$, Lise Aksglaede ${ }^{1}$, Kaspar Soerensen ${ }^{1}$, Casper P Hagen ${ }^{1}$, J H Petersen ${ }^{1,2}$, Katharina M Main ${ }^{1}$ \\ and Anders Juul ${ }^{1}$ \\ ${ }^{1}$ Department of Growth and Reproduction, GR-5064, Copenhagen University Hospital, Rigshospitalet, Blegdamsvej 9, DK-2100 Copenhagen, Denmark \\ and ${ }^{2}$ Department of Biostatistics, University of Copenhagen, Øster Farimagsgade 5, DK-1014 Copenhagen, Denmark
}

(Correspondence should be addressed to A Mouritsen; Email: annette.mouritsen@rh.regionh.dk)

\begin{abstract}
Background: Pubertal onset is usually defined by breast development in girls and testicular growth in boys. Pubarche is defined as the attainment of pubic hair and is considered as a sign of pubertal transition. Pubarche is preceded by a gradual increase in production of adrenal androgens, DHEA and $\Delta 4$-androstenedione (Adione), a process termed adrenarche.

Objective: To study the natural course of pubertal transition and the associations with adrenarche, body fat, and linear growth.

Design and methods: A longitudinal study of 179 healthy children (89 girls) with higher socioeconomic background examined every 6 months for 5 years. Pubic hair stage, breast stage, genital stage, testicular volume (TV), height, weight, and four skinfolds were measured.

Results: In girls, median age (25th and 75th percentiles) at thelarche $(\mathrm{B} 2+)$ was 10.1 years (9.3-10.9). In boys, median age at attaining a TV $>3 \mathrm{ml}$ was 11.5 years (10.9-12.0). Median age at pubarche (PH2 + ) was 10.9 years $(10.3-11.4)$ in girls and 11.6 years $(10.8-12.4)$ in boys. Only $6.8 \%$ (4/59) of the girls and $24.6 \%(15 / 61)$ of the boys developed pubic hair as the first isolated sign of puberty. Serum DHEAS and Adione increased with age, although the increase in Adione was most pronounced in girls. No associations between early age at thelarche/testicular growth and increased body fat (BMI and sum of four skinfolds) were observed.

Conclusion: Danish children rarely experience pubarche as the first sign of puberty. No associations between age at pubertal onset and body composition were found. Circulating levels of Adione, but not DHEAS, increased with the onset of puberty, although with large interindividual variability.
\end{abstract}

European Journal of Endocrinology 168 129-136

\section{Introduction}

The term 'adrenarche' describes the maturation of the adrenal cortex, a developmental process characterized by the activation of adrenal androgen production, principally DHEA and the metabolite, DHEAS, as well as $\Delta 4$-androstenedione (Adione). During fetal development, large amounts of DHEA and DHEAS are produced, but the production decreases rapidly after birth $(1,2)$. The re-activation of the adrenal androgen production has been observed as early as 3 years of age and seems to be a gradual and ongoing process under ACTH stimulation $(3,4)$. This process is reflected by an enlargement of the zona reticularis, resulting in an enzyme profile with low 3 $\beta$-hydroxysteroid dehydrogenase type 2 expression and high cytochrome b5 (enhancer of 17,20-lyase activity of chromosome P450c17) and steroid sulfotransferase (SULT2A1) expression $(5,6)$.
During puberty, DHEA is synthesized in high amounts, but the function of this steroid is still discussed and the physiological role of adrenarche is unknown $(7,8)$. As the increase in adrenal androgens precedes the increase in estrogens in girls, adrenarche has been suggested to be involved in inducing puberty (9). Furthermore, children with premature adrenarche may develop secondary central precocious puberty (CPP) $(6,10)$. Adiposity may play a role for the timing of pubarche, and hormones related to body fat (leptin, insulin, and insulin-like growth factor 1) have been suggested to participate in initiation of adrenarche $(3,11)$. The gradual increase in adrenal androgens precedes the appearance of androgen-dependent body hair, pubic hair (PH2), and axillary hair by peripheral conversion of DHEAS to testosterone and dihydrotestosterone.

Some studies have implicated that girls with premature adrenarche seem to be at increased risk 
of ovarian hyperandrogenism, polycystic ovarian syndrome (12), insulin resistance, and metabolic syndrome $(13,14)$. Therefore, we found it important to study the timing of gonadarche and pubarche and the possible associations with adrenal androgen levels and fat accumulation in healthy Danish children.

\section{Materials and methods}

\section{Subjects}

A total of 208 children participated in the longitudinal part of the Copenhagen Puberty Study. The study was conducted at two schools, both belonging to the upper $20 \%$ of Danish schools who are characterized by higher parental income and socioeconomic status according to a national investigation from 2011, http://krevi.dk/files/ Bilag_2_til_rapport_om_folkeskolens_faglige_kvalitet. pdf. Participants of non-Caucasian origin (17 girls and 11 boys) or with chronic illness (one girl) were excluded from the analyses for this study, resulting in inclusion of a total of 179 children (89 girls) aged 5.9-12.8 years at first examination. The children were examined every 6 months for 5 years (2006-2010).

\section{Clinical examination}

Pubertal stages were evaluated by clinical examination according to Marshall \& Tanner $(15,16)$. Breast stage and testicular volume (TV) were measured by palpation, TV to the nearest millilitre using Prader's orchidometer. In case of discrepancy between left and right side, the largest measurement was used for classification. Pubertal onset was defined as breast stage $\geq \mathrm{B} 2$ in girls and $\mathrm{TV}>3 \mathrm{ml}$ in boys or pubic hair stage $\geq \mathrm{PH} 2$ (pubarche) in girls and boys. Gonadarche was defined as development of secondary sex characteristics due to pituitarygonadal activation (B2 in girls and TV $>3 \mathrm{ml}$ in boys). If breast tissue was palpated at an earlier examination but not present at the subsequent examination, the girl was graded as B1 $(n=6)$. Assessment of pubic hair staging was done by inspection.

All evaluations of puberty in the girls were performed by one of two female pediatricians and all evaluations in boys by one of three male pediatricians. Age at onset of pubic hair $(\mathrm{PH} 2+)$, breast tissue $(\mathrm{B} 2+)$, genital stage 2 $(\mathrm{G} 2+)$, or $\mathrm{TV}>3 \mathrm{ml}$ was assigned as the mean age between age at first examination in stage 2 and the latest examination in stage 1 . Each child had two to ten examinations (median number of examinations: eight in girls and nine in boys). The dropout rate in the study was 39\% (from 179 to 109 children). Boys and girls were divided into quartiles according to age at $\mathrm{B} 2+$ or TV $>3$ ml: girls: Q1 $\leq 9.66$ years, Q2 +Q3 9.66-10.93 years, and $Q 4 \geq 10.93$ years; boys: $Q 1 \leq 10.68$ years, Q2 +Q3 10.68-11.85 years, and Q4 $\geq 11.85$ years.
As illustrated by flowchart (Fig. 1), the onset of breast development (thelarche, B2+) was observed in 42 $(47 \%)$ girls and onset of testicular growth (TV $>3 \mathrm{ml})$ was observed in 44 (49\%) boys during the study period. Pubic hair (pubarche $(\mathrm{PH} 2+)$ ) was attained in 104 $(58 \%)$ children ( 50 girls) during the study period. Girls and boys were also classified according to their first sign of puberty: the girls, who began puberty with breast development alone (the 'thelarche pathway'), the boys, who began puberty with testicular growth above $3 \mathrm{ml}$ alone (the 'testicular pathway'), the girls and boys, who began with pubic hair development alone (the "pubarche pathway'), and the girls and boys, who began with breast development and pubic hair or testicular growth and pubic hair at the same time (the 'synchronous pathway').

Height was measured using a stadiometer (Holtain Ltd., Crymych, UK). Weight was measured using a digital electronic scale (Seca delta, model 707; Seca, Hamburg, Germany). Height was measured to the nearest $0.1 \mathrm{~cm}$ and weight to the nearest $0.1 \mathrm{~kg}$. Height velocity was calculated as the height growth in centimetre per year from previous examination. BMI was calculated as weight $(\mathrm{kg})$ divided by height $\left(\mathrm{m}^{2}\right)$. The thickness of four skinfolds (biceps, triceps, subscapular, and iliac crest) was measured on the left side of the body using a Holtain skinfold caliper calibrated to $0.2 \mathrm{~mm}$ (Harpenden, British Indicators Ltd., London, UK). Biceps: over the midpoint of the muscle belly. Triceps: over the midpoint of the muscle belly, midway between the olecranon, and the tip of the acromion. Subscapular: just below the tip of the inferior angle of the scapula. Suprailiac crest: above the iliac crest along the anterior axillary line $(17,18)$.

\section{Laboratory analyses}

Blood samples were drawn between 0800 and $1000 \mathrm{~h}$. They were clotted, centrifuged, and serums were stored at $-20{ }^{\circ} \mathrm{C}$ until hormone analyses were performed. Serum FSH and LH were measured by time-resolved immunofluorometric assays (Delfia; PerkinElmer, MA, USA) with detection limits of 0.06 and $0.05 \mathrm{IU} / \mathrm{l}$ for FSH and LH respectively. Intra- and interassay coefficients of variation $(\mathrm{CV})$ were $<5 \%$ in both gonadotropin assays. Estradiol $\left(\mathrm{E}_{2}\right)$ levels were determined by RIA (Pantex, Santa Monica, CA, USA) with detection limit of $18 \mathrm{pmol} / \mathrm{l}$ and the intra- and interassay CV were 7.5 and $12.3 \%$ respectively. Testosterone levels were measured with the DPC Coat-A-Count RIA kit (Diagnostic Products, Los Angeles, CA, USA) with detection limit of $0.23 \mathrm{nmol} / \mathrm{l}$ and the intra- and interassay $\mathrm{CV}$ were 7.6 and $8.6 \%$ respectively.

DHEAS and Adione levels were measured by specific solid-phase, competitive chemiluminescent enzyme immunoassays (Immulite 2000; Siemens, USA) with detection limits of $0.41 \mu \mathrm{mol} / \mathrm{l}$ and $1.04 \mathrm{nmol} / \mathrm{l}$ 


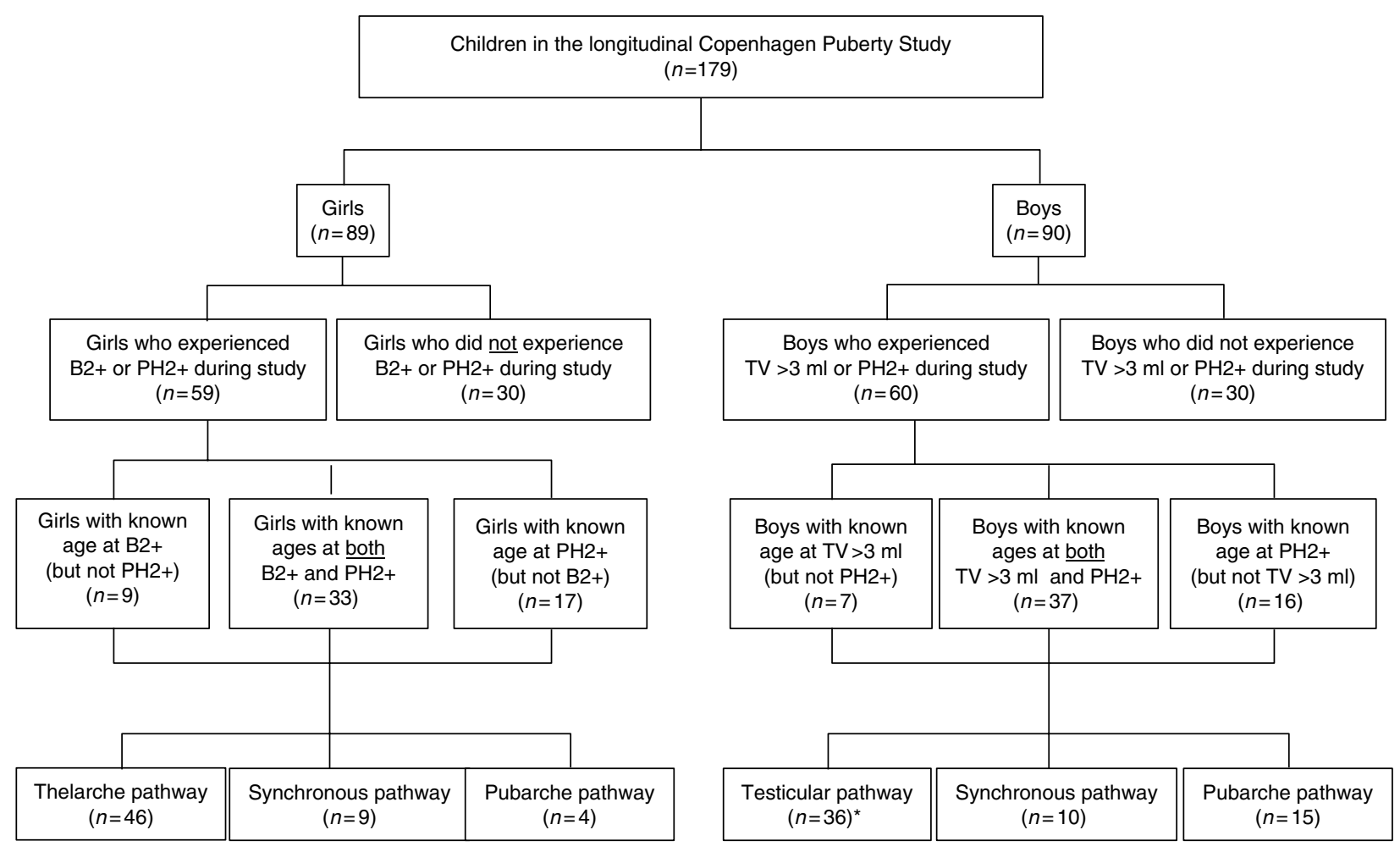

Figure 1 Flowchart illustrating the eligibility and exclusions of 179 healthy children followed longitudinally for 5 years (two to ten examinations per child) in the Copenhagen Puberty Study. ${ }^{*}$ Age at pubarche could not be calculated in one boy with known testicular pathway.

respectively. The intra- and interassay CV were 6.3-7.1 and $7.8-10.2 \%$ and $7.1-10.8$ and $11.0-14.9 \%$ respectively.

\section{Statistical analysis}

To estimate the age at entry into a certain puberty stage (including whether or not attainment of a TV above $3 \mathrm{ml}$ had occurred), a Probit analysis was used. For all individuals, the exact age at entry into a certain puberty stage was unknown. Some individuals had either already entered the stage at the first examination, in which case the current age at examination was known to be an upper bound for the true age at entry (left censored), or the individual had not yet entered the stage at the last examination, in which case the current age was a lower bound (right censored). For some individuals, the person had entered the stage at some examination but had not entered that stage at the previous examination. This yields an interval containing the true age at entry (interval-censored data). Only the interval in which the change occurred was included. Thus, no participants were included with multiple measurements. The Probit analysis takes properly into account the prospective follow-up study design and the three kinds of censoring.

The results are presented as median age at entry into the different pubertal stages as well as the 25 th and 75 th percentiles in the age at entry distribution. Levels of DHEAS and Adione 1 year before and 1 year after pubertal onset were compared by Wilcoxon signed rank test.

Statistical analyses were carried out using the SPSS Software (version 19; SPSS, Inc., Chicago, IL, USA) and the SAS Software (SAS 9: SAS Institute, Inc., Cary, NC, USA).

\section{Ethical considerations}

The Copenhagen Puberty Study was approved by the Local Ethics Committee (\#KF 01282214 and \#V200.1996/90) and conducted in accordance with the Second Helsinki Declaration. The study is registered in ClinicalTrials.gov (identifier NCT01411527). All children and parents received written information and were invited to an information meeting. All children and their parents gave informed consent.

\section{Results}

Based on the entire cohort, girls experienced pubarche $(\mathrm{PH} 2+)$ at a median age of 10.9 years and thelarche $(\mathrm{B} 2+)$ at 10.1 years (Tables 1 and 2$)$. In girls, where pubertal onset could be tracked, median ages at pubarche and thelarche were $10.8(n=50)$ and 10.3 $(n=42)$ years respectively. Four of 59 girls $(6.8 \%)$ 
Table 1 Median age at $\mathrm{B} 2+$ and $\mathrm{PH} 2+$ by initiating pathway in 59 girls.

\begin{tabular}{lrrrrr}
\hline & \multicolumn{2}{c}{ Age at B2 +} & & \multicolumn{2}{c}{ Age at PH2+ } \\
\cline { 2 - 3 } \cline { 5 - 6 } & Median $^{\mathrm{a}}$ & 25th-75th percentiles & & Median $^{\text {a }}$ & 25th-75th percentiles \\
\hline Entire cohort $(n=89)$ & 10.07 & $9.29-10.86$ & & 10.85 & $10.30-11.41$ \\
$\quad$ Girls with known pathway $(n=59)$ & & & & 10.98 & $10.50-11.46$ \\
$\quad$ Thelarche pathway $(n=46)$ & 9.69 & $9.09-10.29$ & & 10.75 & $10.35-11.16$ \\
$\quad$ Synchronous $(n=9)$ & 10.75 & $10.35-11.16$ & & 10.37 & $9.87-10.86$ \\
$\quad$ Pubarche $(n=4)$ & 12.61 & $12.10-13.12$ & & \\
\hline
\end{tabular}

${ }^{a}$ Median age at entry into puberty determined by Probit analyses taking left-, right-, and interval-censoring into account.

entered puberty by the 'pubarche pathway' by developing pubic hair as the first sign of puberty, 46/59 $(78.0 \%)$ by the 'thelarche pathway' by developing breast tissue as the first sign of puberty, and 9/59 $(15.3 \%)$ by the 'synchronous pathway'. Noteworthy, six of the girls in the study developed breast tissue at one examination, which disappeared at the subsequent examination. Based on the entire cohort, boys experienced pubarche $(\mathrm{PH} 2+)$ at a median age of 11.6 years and testicular growth (TV $>3 \mathrm{ml}$ ) at 11.5 years (Tables 1 and 2). In boys, where pubertal onset could be tracked, median ages at pubarche and TV $>3 \mathrm{ml}$ were 11.8 $(n=53)$ and $11.5(n=44)$ years respectively. Fifteen of 61 boys $(24.6 \%)$ entered puberty by the "pubarche pathway', 36/61 (59.0\%) by the 'testicular pathway', and 10/61 (16.4\%) by the 'synchronous pathway'.

Adrenal androgen levels (DHEAS and Adione) increased with age and with time to gonadarche and pubarche in both sexes (Figs 2 and 3). The median level (25th and 75th percentiles) of DHEAS increased in girls from $0.5 \mu \mathrm{mol} / \mathrm{l}(<0.41-1.2)$ at 8 years of age to $1.7 \mu \mathrm{mol} / \mathrm{l}(1.1-2.5)$ at 13 years of age and in boys from $0.6 \mu \mathrm{mol} / \mathrm{l}(<0.41-0.9)$ at 8 years of age to $3.0 \mu \mathrm{mol} / \mathrm{l}$ $(1.6-3.6)$ at 13 years of age. Adione increased in girls from $<1.04 \mathrm{nmol} / \mathrm{l}(<1.04-1.6)$ at 8 years of age to $4.9 \mathrm{nmol} / \mathrm{l}(3.6-7-9)$ at 13 years of age in girls and from $<1.04 \mathrm{nmol} / \mathrm{l}(<1.04-<1.04)$ at 8 years of age to $3.2 \mathrm{nmol} / \mathrm{l}(2.1-4.4)$ at 13 years of age in boys. The level of Adione, but not the level of DHEAS, increased earlier in girls compared with boys (Figs 2A and $\mathrm{D}, 3 \mathrm{~A}$ and $\mathrm{D})$. The level of Adione increased markedly with the onset of gonadarche and pubarche (Figs 2E and F, 3E and F). In girls, the level of DHEAS increased from $1.1 \mu \mathrm{mol} / \mathrm{l} 1$ year before breast development to $1.6 \mu \mathrm{mol} / \mathrm{l} 1$ year after breast development
$(P=0.008)$, and Adione increased from 1.3 to $3.0 \mathrm{nmol} / \mathrm{l}(P=0.008)$. In boys, the level of DHEAS increased from $1.7 \mu \mathrm{mol} / \mathrm{l} 1$ year before testicular growth to $2.7 \mu \mathrm{mol} / \mathrm{l} 1$ year after testicular growth $(P=0.000)$, and Adione increased from 1.3 to $2.7 \mathrm{nmol} / \mathrm{l}(P=0.001)$. There was a large interindividual variability in the level of adrenal androgens with no apparent hormonal cutoff value corresponding to gonadarche or pubarche (Figs 2B, C, E and F, 3B, C, E and F).

The levels of adrenal androgens, BMI, skin folds, height, and height velocity according to age at B2 +/TV $>3 \mathrm{ml}$ are illustrated in Supplementary Figs 1 and 2, see section on supplementary data given at the end of this article. An earlier rise in the level of Adione, but not DHEAS, was seen in both girls and boys with early age at $\mathrm{B} 2+/ \mathrm{TV}>3 \mathrm{ml}(\mathrm{Q} 1)$ compared with average or later $\mathrm{B} 2+/ \mathrm{TV}>3 \mathrm{ml}(\mathrm{Q} 2+\mathrm{Q} 3$ and Q4) (Supplementary Figs $1 \mathrm{~A}$ and $\mathrm{B}, 2 \mathrm{~A}$ and $\mathrm{B})$.

A large interindividual variability in BMI and sum of four skinfolds during the pubertal transition were observed. BMI, but not the sum of four skinfolds, increased with age. Girls with earlier thelarche $(\mathrm{Q} 1)$ were taller and experienced an earlier pubertal growth spurt compared with those with average $(\mathrm{Q} 2+\mathrm{Q} 3)$ or later thelarche (Q4). Boys with earlier testicular growth (Q1) were not taller but seem to experience an earlier and more pronounced growth spurt compared with those with average $(\mathrm{Q} 2+\mathrm{Q} 3)$ or later testicular growth.

The steep increases in Adione and $\mathrm{E}_{2}$ levels were not observed in the few girls entering puberty by the 'pubarche pathway' compared with girls entering puberty by the 'thelarche pathway' or the 'synchronous pathway', although no differences in the levels of DHEAS between pathways were observed (Supplementary Fig. 3, see section on supplementary data

Table 2 Median age at $\mathrm{PH} 2+$ and TV $>3 \mathrm{ml}$ by initiating pathway in 61 boys.

\begin{tabular}{|c|c|c|c|c|}
\hline & \multicolumn{2}{|c|}{ Age at $\mathrm{TV}>3 \mathrm{ml}$} & \multicolumn{2}{|c|}{ Age at $\mathrm{PH} 2+$} \\
\hline & Median $^{\mathrm{a}}$ & 25th-75th percentiles & Median $^{\mathrm{a}}$ & 25th-75th percentiles \\
\hline $\begin{array}{l}\text { Entire cohort }(n=90) \\
\text { Boys with known pathway }(n=61)\end{array}$ & 11.45 & $10.87-12.04$ & 11.59 & $10.77-12.41$ \\
\hline Testicular pathway $(n=36)$ & 11.21 & $10.71-11.70$ & 12.00 & $11.40-12.60$ \\
\hline Synchronous $(n=10)$ & 11.78 & $11.11-12.44$ & 11.78 & $11.11-12.44$ \\
\hline Pubarche $(n=15)$ & 11.51 & $10.90-12.12$ & 10.03 & $10.39-10.67$ \\
\hline
\end{tabular}

${ }^{a}$ Median age at entry into puberty determined by Probit analyses taking left-, right-, and interval-censoring into account. 

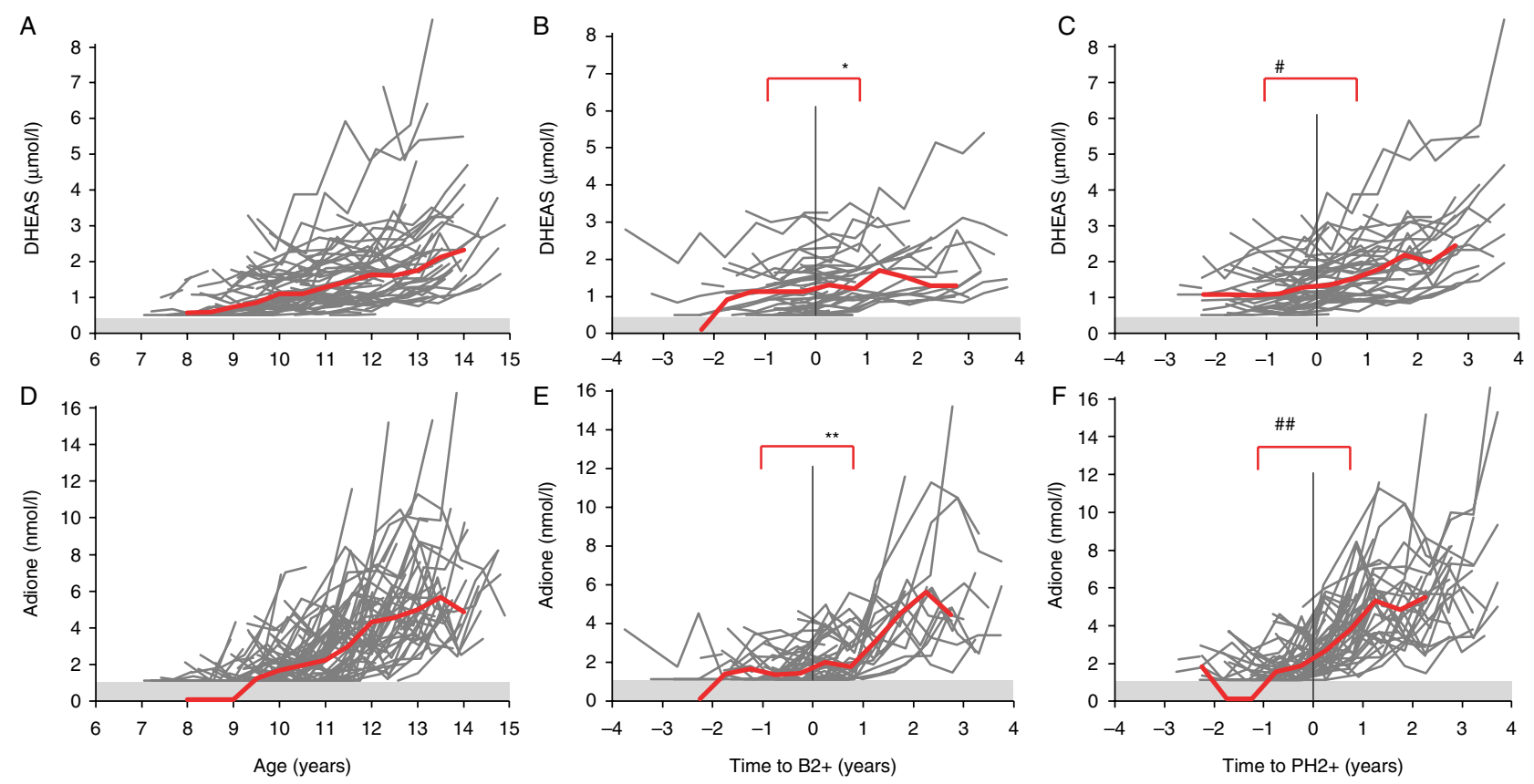

Figure 2 Longitudinal serum levels of DHEAS (A, B and C) and $\triangle 4$-androstenedione (Adione; D, E and F) according to age (A and D), time to $\mathrm{B} 2+(\mathrm{B}$ and $\mathrm{E})$, and time to $\mathrm{PH} 2+(\mathrm{C}$ and $\mathrm{F}$ ) in healthy girls. Lines represent longitudinal values in the 42 and the 50 (out of 89 ) girls where onset of $\mathrm{B} 2$ and $\mathrm{PH} 2$ respectively could be tracked. The red line illustrates median values. *Significant difference between DHEAS levels 1 year before and 1 year after thelarche in girls $(P=0.008)$. "Significant difference between DHEAS levels 1 year before and 1 year after pubarche in girls $(P=0.000) .{ }^{*}$ Significant difference between Adione levels 1 year before and 1 year after thelarche in girls $(P=0.008) .{ }^{\# \#}$ Significant difference between Adione levels 1 year before and 1 year after pubarche in girls $(P=0.000)$.

given at the end of this article). In boys, no differences in the levels of DHEAS, Adione, or testosterone between pathways were observed.

\section{Discussion}

In this longitudinal study, we describe adrenal androgen secretion during the pubertal transition in healthy children. Obviously, others have suggested an increase in adrenal androgens with age but based on crosssectional data $(19,20)$. Few longitudinal studies of adrenal function in children exist, and these are primarily based on very few subjects (21) or urinary samples $(22,23)$. In addition, some studies based on longitudinally collected serum samples from patients with exaggerated adrenarche exist (24). To our knowledge, this is the only longitudinal study with repetitive collection of serum samples based on healthy children.

\section{Pubarche}

In this longitudinal cohort study of pubertal transition based on healthy Danish girls and boys, median ages at first pubic hair development were 10.9 and 11.6 years respectively. In our Danish study, only $7 \%$ of the girls developed pubic hair as the first sign of pubertal onset, whereas this was the case in $25 \%$ of the boys. Interestingly, pubic hair as the first sign of puberty was observed approximately four times more frequently in boys than in girls.

Pubarche appears to start at slightly younger age in our present longitudinal study compared with previous cross-sectional studies, but overall, the results correspond well with our data from Denmark (11.09 for girls and 12.38 for boys) $(25,26)$ and with the data from US (10.6 and 12.0 years respectively) (27). The marginal differences may be due to the fact that the age at entering a certain stage $(\mathrm{PH} 2+)$ differs from the age of being in a stage (PH2). However, only marginal differences exist between ages at entry into the various pubertal stages in the entire cohort compared with the selected group of children in whom the pubertal onset could be tracked.

\section{Pubertal pathways}

In girls, the onset of puberty was defined as either development of pubic hair (PH2) or breast tissue (B2) as suggested by Biro et al. (28). In girls, the majority entered puberty by the 'thelarche pathway' or the 'synchronous pathway', and only $6.8 \%$ of the girls entered puberty by the 'pubarche pathway'. Our results were similar to data from Norway, where $8.4 \%(16 / 190)$ entered puberty by the pubarche pathway (29), whereas the prevalence of girls entering puberty by the pubarche pathway was $11.6 \%$ in a UK study and $14.5 \%$ in a US study $(28,30)$. In a mixed population of black and white US girls, the prevalence was even higher (31). 

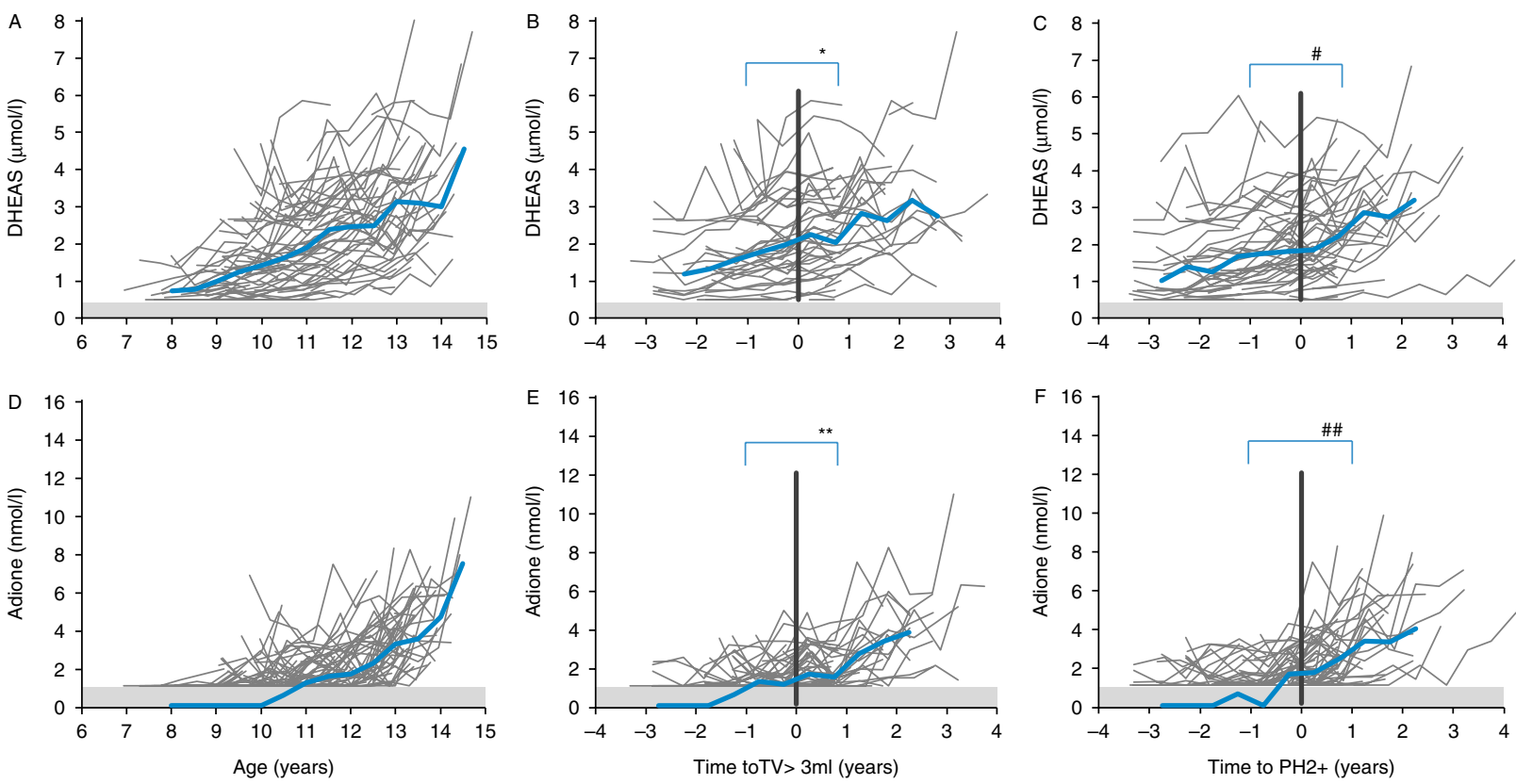

Figure 3 Longitudinal serum levels of DHEAS (A, B and C) and $\triangle 4$-androstenedione (Adione; D, E and F) according to age (A and D), time to testicular growth ( $T V>3 \mathrm{ml} ; \mathrm{B}$ and $\mathrm{E})$, and time to $\mathrm{PH} 2+(\mathrm{C}$ and $\mathrm{F}$ ) in healthy boys. Lines represent longitudinal values in the 44 and the 53 (out of 90) boys where onset of TV $>3 \mathrm{ml}$ and $\mathrm{PH} 2$ respectively could be tracked. The blue line illustrates median values. ${ }^{*}$ Significant difference between DHEAS levels 1 year before and 1 year after testicular growth in boys $(P=0.000)$. "Significant difference between DHEAS levels 1 year before and 1 year after pubarche in boys $(P=0.000)$. ${ }^{*}$ Significant difference between Adione levels 1 year before and 1 year after testicular growth in boys $(P=0.001)$. \#"Significant difference between Adione levels 1 year before and 1 year after pubarche in boys $(P=0.001)$.

Likewise, the percentage of girls entering puberty through the 'synchronous pathway' was lower $(15.3 \%)$ in our study compared with the Norwegian study (26.3\%) and the US studies (46.3 and $55.7 \%$ respectively). The difference might reflect the different study designs; one study (29) combining one clinical examination with a later completion of a self-assessment form and another study (28) being longitudinal with annual examinations. The differences could also reflect differences in body fat content between the Scandinavian and the US adolescents. In addition, genetic/ethnic, environmental, and lifestyle factors not associated with body composition may also play a role.

Girls entering puberty by the 'pubarche pathway' show an increase in DHEAS, but not in Adione and $\mathrm{E}_{2}$ as opposed to the girls entering puberty by the other pathways. This indicates that circulating steroids are primarily derived from the adrenals in these girls. Thus, the increase in Adione in the latter groups could partly be mediated by activation of the hypothalamicpituitary-ovarian axis leading to ovarian production of Adione (32). In accordance, it has been shown that the ovaries contribute to $50 \%$ of the Adione production in premenopausal women (33). A contribution to pubic hair development by androgens from the ovaries is supported by results from a study of girls with Turner syndrome with primary ovarian failure who, regardless of high levels of DHEAS, developed pubic hair later (34). Early pubarche has been suggested to be associated with risk of ovarian hyperandrogenism (12). As shown in
Supplementary Fig. 3C, we cannot evaluate Adione levels in pubarche pathway girls above 14 years of age due to the design of our study and therefore cannot exclude development of ovarian hyperandrogenism later in life.

In boys, the prevalence of pubarche as the first sign of puberty was higher than in girls. In a longitudinal study of 84 boys, Biro et al. (35) observed only four boys with pubic hair and TV $\leq 3 \mathrm{ml}$ ('pubarche pathway') compared with 39 boys with TV $>3 \mathrm{ml}$ and no pubic hair ('testicular pathway'). In another longitudinal US study, not reporting TV, Susman et al. (31) reported genital stage as the first sign of puberty in the majority of boys $(91 \%(389 / 427))$.

\section{Body fat}

In general, it is believed that an inverse association exists between body fat and age puberty. In girls, we did not observe apparent differences in BMI or sum of four skinfolds between those with earliest thelarche compared with the others, although it is difficult to draw cause and effect between the timing of the onset of puberty and the preexisting body composition as most children were more than 9 years when examined. Furthermore, these data are limited to BMI and thickness of four skinfolds. BMI does not necessarily reflect body fat, as we have earlier shown that girls with CPP had similar BMI, but significantly increased total body fat percentage by dual-energy X-ray absorptiometry compared with controls (36). 
In boys, we found no association between early age at onset of testicular growth and increased body fat (BMI and sum of four skinfolds). In accordance with these findings, a study reported no associations between age at pubarche/adrenarche and markers of body fat, glucose, and insulin in boys with premature pubarche (37). By contrast, one US study reported that boys with lower BMI were less likely to enter puberty through the pubarche pathway (38) and another study observed an association between higher level of adrenal androgens and higher BMI in boys (39).

\section{Height and height velocity}

Timing of puberty was associated with height in girls and with height velocity in both sexes. Although the height was measured every 6 months, the children, especially the girls, grew rapidly throughout the peripubertal period and the individual pubertal growth spurts were not as clearly depicted as anticipated. We speculate that this is partly caused by the early maturing girls who might already have had their growth spurt, as other studies have shown that a proportion of girls have their growth spurt before reaching B2.

\section{Adrenal androgens}

Circulating levels of Adione, but not DHEAS, increased with the onset of puberty, although with large interindividual variability. Furthermore, a steeper increase of Adione was seen in girls than in boys.

A gender difference in the level of Adione and in the ratio of DHEAS/Adione exists, supported by a study of Korth-Schuz et al. (1976) (19). The gender difference may be derived from ovarian vs testicular production of Adione or derived from differences in the activity of 17,20 lyase, which converts steroidal precursors to C19 steroids. As adrenarche is an event unique to humans and a few other primate species, the research in this field is limited, but animal studies suggest a sex difference in the production of adrenal androgens (40). In this longitudinal study, an association between Adione and $\mathrm{E}_{2}$ is observed, which could be explained by the ovarian contribution of androgen production.

The marked interindividual variability in adrenal androgen levels at the time of pubertal onset, as well as the marked gender differences, imply that other factors like androgen sensitivity in peripheral target tissues must play a role.

\section{Limitations}

The study is limited due to lack of completeness of data as breast development and testicular growth could only be tracked in half of the included children. However, age at entry into the various pubertal signs did not differ between the group in whom age at pubertal onset was observed and the entire cohort. Furthermore, the children included in our study may not be representative for all Danish children as both schools have students with higher than average socioeconomic background.

In conclusion, the majority of healthy Danish children start puberty by breast development or testicular growth before development of pubic hair. No associations with age at pubertal onset and body composition were found in either of the sexes. Circulating levels of Adione, but not of DHEAS, increased with the onset of puberty, although with large interindividual variability. The distinct increase in Adione levels in girls at pubertal onset was most likely due to increased ovarian contribution to the circulating levels of androgens.

\section{Supplementary data}

This is linked to the online version of the paper at http://dx.doi.org/10. 1530/EJE-12-0191.

\section{Declaration of interest}

The authors declare that there is no conflict of interest that could be perceived as prejudicing the impartiality of the research reported.

\section{Funding}

This study was supported by the Sawmill Owner Jeppe Juhl and wife Ovita Juhls Memorial Fund, Aase and Einar Danielsen Foundation, Kirsten and Freddy Johasen Foundation, EU FP7 (DEER; grant agreement no. 212844) and Danish Council for Strategic Research 2009 (DAN-ED; grant agreement no. 2107-05-0006).

\section{References}

1 Belgorosky A, Baquedano MS, Guercio G \& Rivarola MA. Adrenarche: postnatal adrenal zonation and hormonal and metabolic regulation. Hormone Research 200870 257-267. (doi:10.1159/000157871)

2 Bech K, Tygstrup I \& Nerup J. The involution of the foetal adrenal cortex. A light microscopic study. Acta Pathologica et Microbiologica Scandinavica $1969 \mathbf{7 6}$ 391-400. (doi:10.1111/j.1699-0463. 1969.tb03270.x)

3 Palmert MR, Hayden DL, Mansfield MJ, Crigler JF Jr, Crowley WF Jr, Chandler DW \& Boepple PA. The longitudinal study of adrenal maturation during gonadal suppression: evidence that adrenarche is a gradual process. Journal of Clinical Endocrinology and Metabolism 2001 86 4536-4542. (doi:10.1210/jc.86.9.4536)

4 Remer T, Boye KR, Hartmann MF \& Wudy SA. Urinary markers of adrenarche: reference values in healthy subjects, aged 3-18 years. Journal of Clinical Endocrinology and Metabolism 200590 2015-2021. (doi:10.1210/jc.2004-1571)

5 Ibanez L, Dimartino-Nardi J, Potau N \& Saenger P. Premature adrenarche - normal variant or forerunner of adult disease? Endocrine Reviews 200021 671-696. (doi:10.1210/er.21.6.671)

6 Auchus RJ \& Rainey WE. Adrenarche - physiology, biochemistry and human disease. Clinical Endocrinology 200460 288-296. (doi:10.1046/j.1365-2265.2003.01858.x)

7 Grumbach MM, Roth JC, Kaplan SL \& Kelch RP. Hypothalamicpituitary regulation of puberty in man: evidence and concepts derived from clinical research. In Control of the Onset of Puberty, pp 115-166. Eds MM Grumbach, GD Grave \& FE Fayer, New York: Wiley, 1974. 
8 Reiter EO \& Grumbach MM. Neuroendocrine control mechanisms and the onset of puberty. Annual Review of Physiology $1982 \mathbf{4 4}$ 595-613. (doi:10.1146/annurev.ph.44.030182.003115)

9 Ducharme JR, Forest MG, De Peretti E, Sempe M, Collu R \& Bertrand J. Plasma adrenal and gonadal sex steroids in human pubertal development. Journal of Clinical Endocrinology and Metabolism 197642 468-476. (doi:10.1210/jcem-42-3-468)

10 Sopher AB, Jean AM, Zwany SK, Winston DM, Pomeranz CB, Bell JJ, McMahon DJ, Hassoun A, Fennoy I \& Oberfield SE. Bone age advancement in prepubertal children with obesity and premature adrenarche: possible potentiating factors. Obesity 201119 1259-1264. (doi:10.1038/oby.2010.305)

11 Smith CP, Dunger DB, Williams AJ, Taylor AM, Perry LA, Gale EA, Preece MA \& Savage MO. Relationship between insulin, insulinlike growth factor I, and dehydroepiandrosterone sulfate concentrations during childhood, puberty, and adult life. Journal of Clinical Endocrinology and Metabolism 198968 932-937. (doi:10.1210/ jcem-68-5-932)

12 Ibanez L, Potau N \& Carrascosa A. Insulin resistance, premature adrenarche, and a risk of the polycystic ovary syndrome (PCOS). Trends in Endocrinology and Metabolism $1998 \quad \mathbf{9}$ 72-77. (doi:10.1016/S1043-2760(98)00014-9)

13 Idkowiak J, Lavery GG, Dhir V, Barrett TG, Stewart PM, Krone N \& Arlt W. Premature adrenarche - novel lessons from early onset androgen excess. European Journal of Endocrinology $2011 \mathbf{1 6 5}$ 189-207. (doi:10.1530/EJE-11-0223)

14 Denburg MR, Silfen ME, Manibo AM, Chin D, Levine LS, Ferin M, McMahon DJ, Go C \& Oberfield SE. Insulin sensitivity and the insulin-like growth factor system in prepubertal boys with premature adrenarche. Journal of Clinical Endocrinology and Metabolism 2002 87 5604-5609. (doi:10.1210/jc.2002-020896)

15 Marshall WA \& Tanner JM. Variations in pattern of pubertal changes in girls. Archives of Disease in Childhood $1969 \mathbf{4 4}$ 291-303. (doi:10.1136/adc.44.235.291)

16 Marshall WA \& Tanner JM. Variations in the pattern of pubertal changes in boys. Archives of Disease in Childhood 197045 13-23. (doi:10.1136/adc.45.239.13)

17 Tanner JM \& Whitehouse RH. Standards for subcutaneous fat in British children. Percentiles for thickness of skinfolds over triceps and below scapula. BMJ 19621 446-450. (doi:10.1136/bmj.1. 5276.446)

18 Harrison GG, Buskirk ER, Lindsay Carter JE et al. Skinfold thickness and measurement technique. In Anthropometric Standardization Reference Manual, pp 55-70. Eds TG Lohman, AF Roche \& R Martorell, Human Kinetics Books, 1988.

19 Korth-Schutz S, Levine LS \& New MI. Serum androgens in normal prepubertal and pubertal children and in children with precocious adrenarche. Journal of Clinical Endocrinology and Metabolism 1976 42 117-124. (doi:10.1210/jcem-42-1-117)

20 Meikle AW, Kushnir MM, Rockwood AL et al. Adrenal steroid concentrations in children seven to seventeen years of age. Journal of Pediatric Endocrinology \& Metabolism 2007 20 1281-1291.

21 Sizonenko PC, Paunier L \& Carmignac D. Hormonal changes during puberty. IV. Longitudinal study of acrenal androgen secretions. Hormone Research 19767 288-302. (doi:10.1159/000178740)

22 Remer T \& Manz F. Role of nutritional status in the regulation of adrenarche. Journal of Clinical Endocrinology and Metabolism 1999 84 3936-3944. (doi:10.1210/jc.84.11.3936)

23 Shi L, Wudy SA, Buyken AE, Hartmann MF \& Remer T. Body fat and animal protein intakes are associated with adrenal androgen secretion in children. American Journal of Clinical Nutrition 2009 90 1321-1328. (doi:10.3945/ajcn.2009.27964)

24 Paterson WF, Ahmed SF, Bath L, Donaldson MD, Fleming R, Greene SA, Hunter I, Kelnar CJ, Mayo A, Schulga JS et al. Exaggerated adrenarche in a cohort of Scottish children: clinical features and biochemistry. Clinical Endocrinology 2010 72 496-501. (doi:10.1111/j.1365-2265.2009.03739.x)

25 Aksglaede L, Sorensen K, Petersen JH, Skakkebaek NE \& Juul A. Recent decline in age at breast development: the Copenhagen Puberty Study. Pediatrics 2009123 e932-e939. (doi:10.1542/ peds.2008-2491)
26 Sorensen K, Aksglaede L, Petersen JH \& Juul A. Recent changes in pubertal timing in healthy Danish boys: associations with body mass index. Journal of Clinical Endocrinology and Metabolism 2010 95 263-270. (doi:10.1210/jc.2009-1478)

27 Sun SS, Schubert CM, Chumlea WC, Roche AF, Kulin HE, Lee PA, Himes JH \& Ryan AS. National estimates of the timing of sexual maturation and racial differences among US children. Pediatrics 2002110 911-919. (doi:10.1542/peds.110.5.911)

28 Biro FM, Huang B, Daniels SR \& Lucky AW. Pubarche as well as thelarche may be a marker for the onset of puberty. Journal of Pediatric and Adolescent Gynecology 200821 323-328. (doi:10.1016/j.jpag.2007.09.008)

29 Ogland B, Nilsen ST, Forman MR \& Vatten LJ. Pubertal development in daughters of women with pre-eclampsia. Archives of Disease in Childhood 201196 740-743. (doi:10.1136/adc. 2009.178434)

30 Christensen KY, Maisonet M, Rubin C, Holmes A, Dana Flanders W, Heron J, Golding J, McGeehin MA \& Marcus M. Pubertal pathways in girls enrolled in a contemporary British cohort. International Journal of Pediatrics $2010 \mathbf{2 0 1 0} 329261$. (doi:10.1155/2010/329261)

31 Susman EJ, Houts RM, Steinberg L, Belsky J, Cauffman E, Dehart G, Friedman SL, Roisman GI \& Halpern-Felsher BL. Longitudinal development of secondary sexual characteristics in girls and boys between ages 91/2 and 151/2 years. Archives of Pediatrics $\mathcal{E}$ Adolescent Medicine 2010164 166-173. (doi:10.1001/archpediatrics.2009.261)

32 Patel SS, Beshay VE, Escobar JC \& Carr BR. 17 $\alpha$-Hydroxylase (CYP17) expression and subsequent androstenedione production in the human ovary. Reproductive Sciences $2010 \mathbf{1 7} 978-986$. (doi:10.1177/1933719110379055)

33 Labrie F, Luu-The V, Labrie C \& Simard J. DHEA and its transformation into androgens and estrogens in peripheral target tissues: intracrinology. Frontiers in Neuroendocrinology 200122 185-212. (doi:10.1006/frne.2001.0216)

34 Martin DD, Schweizer R, Schwarze CP, Elmlinger MW, Ranke MB \& Binder G. The early dehydroepiandrosterone sulfate rise of adrenarche and the delay of pubarche indicate primary ovarian failure in Turner syndrome. Journal of Clinical Endocrinology and Metabolism 200489 1164-1168. (doi:10.1210/jc.2003031700)

35 Biro FM, Lucky AW, Huster GA \& Morrison JA. Pubertal staging in boys. Journal of Pediatrics 1995127 100-102. (doi:10.1016/ SO022-3476(95)70265-2)

36 Sorensen K, Mouritsen A, Mogensen SS, Aksglaede L \& Juul A. Insulin sensitivity and lipid profiles in girls with central precocious puberty before and during gonadal suppression. Journal of Clinical Endocrinology and Metabolism $2010 \quad 95$ 3736-3744. (doi:10.1210/jc.2010-0731)

37 Potau N, Ibanez L, Rique S, Sanchez-Ufarte C \& de Zegher F. Pronounced adrenarche and precocious pubarche in boys. Hormone Research 199951 238-241. (doi:10.1159/000023377)

38 Schubert CM, Chumlea WC, Kulin HE, Lee PA, Himes JH \& Sun SS. Concordant and discordant sexual maturation among U.S. children in relation to body weight and BMI. Journal of Adolescent Health 200537 356-362. (doi:10.1016/j.jadohealth.2005.03.009)

39 Arquitt AB, Stoecker BJ, Hermann JS \& Winterfeldt EA. Dehydroepiandrosterone sulfate, cholesterol, hemoglobin, and anthropometric measures related to growth in male adolescents. Journal of the American Dietetic Association 199191 575-579.

40 Rehman KS \& Carr BR. Sex differences in adrenal androgens. Seminars in Reproductive Medicine 200422 349-360. (doi:10.1055/ s-2004-861551)

Received 2 March 2012

Revised version received 14 September 2012

Accepted 23 October 2012 